\title{
THE QUALITY OF MEAT AND EGGS OF LAYING HENS WHEN ADDING SUCCINIC ACID DRUG TO THE DIET
}

\author{
SERGEY YU. SMOLENTSEV ${ }^{1}$, IRINA I. STRELNIKOVA ${ }^{1 *}$, ALISYA R. GABDRAKHMANOVA ${ }^{2}$, \\ ALINYA R. NURGALIEVA ${ }^{2}$, ELMIRA M. KOSACHEVA ${ }^{2}$, GALINA S. STEPANOVA ${ }^{2}$, ALBINA V. \\ POTAPOVA ${ }^{2}$, LEYSAN V. ABDULLINA ${ }^{2}$, SVETLANA N. SAVDUR ${ }^{2}$, ANDREY A. RUDENKO ${ }^{3}$, OLGA I. \\ SHORKINA ${ }^{4}$, ILSUR G. GALIMZYANOV ${ }^{4}$, NIKITA V. NIKOLAEV ${ }^{4} \&$ EVGENY O. KRUPIN $^{5}$ \\ ${ }^{1}$ Mari State University, Lenin Square 1, Yoshkar-Ola City, 424000, Russia \\ ${ }^{2}$ Kazan cooperative institute (branch) Russian university of cooperation, 58 Ershova str., Kazan, Russia \\ ${ }^{3}$ Moscow State University of Food Production, Volokolamsk sh. 11, Moscow City, 125080, Russia \\ ${ }^{4}$ Kazan State Academy of Veterinary Medicine by N.E. Bauman, Sibirsky Tract 35, Kazan City, 420029, Russia
}

${ }^{5}$ Tatar Scientific Research Institute of Agriculture, FRC Kazan Scientific Center, Russian Academy of Sciences, Orenburg Tract 48, Kazan City, 420059, Russia

\begin{abstract}
Recently, the use of ecologically safe and biologically active elements and drugs that have a positive impact on the biochemical, immunological, hematological and productive indicators of animals and birds have become of great importance in their feeding. In this regard, the use of extracts of a number of plants, probiotics, as well as organic acids and other additives of natural origin is of great interest. The studies were conducted on laying hens of the cross Rodonit, 180 days of age, on the basis of the Department of Therapy and Clinical Diagnostics of Kazan State Academy of Veterinary Medicine. The first group served as a biological control and received only the basic ration. The drug Yantovet was added to the drinking water at a dose of $0.5 \mathrm{ml} / 1$ bird per day for 60 days in the experimental group. Studies have shown that the use of the drug based on succinic acid and organic phosphorus in addition to the basic ration of laying hens showed a stimulating effect on egg production, while not having a negative impact on product quality

KEYWORDS: Meat Quality, Egg Quality, Succinic Acid, Laying Hens, Safety, Feed Additive
\end{abstract}

Received: Jun 01, 2020; Accepted: Jun 20, 2020; Published: Jul 11, 2020; Paper Id.: IJMPERDJUN2020280

\section{INTRODUCTION}

Life activity and productivity of animals depends on the intake of essential nutrients in the body, providing a certain amount of energy involved in the body's metabolic processes (Khristoforovich et al., 2016; Smolentsev et al., 2018). The imbalance of diets in macro- and microelements, vitamins and other biologically active agents leads to a decrease in productive and reproductive functions and to a decrease in the body's resistance to negative environmental factors (Semenov et al., 2018).

The development of fundamentally new effective preventive measures aimed at increasing the body resistance and productivity of farm animals through the use of environmentally safe products, natural metabolites, actively influencing the energy metabolism in the body is of great importance in modern conditions of livestock breeding (Ilyasovich et al., 2016; Egorov et al., 2018). They possess adaptogenic properties, and their influence on the animal's body is characterized by its physiology (Matveeva et al., 2015; Dmitriyevich et al., 2016). These biologically active substances can increase the general resistance of the body without any disturbances in digestion and metabolism. In recent years, dicarboxylic acids and their derivatives have been actively studied as functional 

Kosacheva, Galina S. Stepanova, Albina V. Potapova, Leysan V. Abdullina, Svetlana N. Savdur, Andrey A. Rudenko, Olga I. Shorkina, Ilsur G. Galimzyanov, Nikita V. Nikolaev, Evgeny O. Krupin stimulants, and their use has great practical significance for both mammals and birds (Popov et al., 2018).

Organic acids have antistress effect, prevent microbial colonization in the gastrointestinal tract, and have a favorable effect on the digestibility and absorption of nutrients. One of such organic acids is succinic acid. It participates in a number of biochemical reactions of the energy, structural and enzymatic support of the organism. Succinic acid stimulates the growth of animals, increases their body resistance, normalizes hematopoiesis (Anatolievna et al., 2016; Valiullin et al., 2017; Samsonov et al., 2018).

In this regard, research on the study of egg production, quality indicators of meat and eggs obtained from laying hens with the injection into their bodies of a new product containing succinic acid and organic phosphorus that we named Yantovet are of great scientific and practical interest.

\section{MATERIALS AND METHODS}

Experimental studies of the effect of the studied drug were carried out in the conditions of the Department of Therapy and Clinical Diagnostics of Kazan State Academy of Veterinary Medicine on 40 laying hens of the Rodonit cross, 180 days of age, divided according to the principle of analogues into two groups. The first group served as a control and received the basic ration (complete feed). The test drug in a dose of $0.5 \mathrm{ml} / 1$ bird per day was added to the drinking water for two months with a cycle of 10 days in the experimental group. Stocking density, light regime and front of feeding for birds of all groups were the same.

When conducting research, we took into account the live weight of the bird, which was determined by individual weighing every 20 days; the mass of the eggs was studied by the average sample (10 eggs) every month with the evaluation according to the methods of FSC “All-Russian Research and Technological Poultry Institute" RAS. The veterinary-sanitary assessment of the meat of laying hens killed after the experiment was carried out by standard methods. The meat was studied after ageing at a temperature of $0-+4 \mathrm{C}$. Material for the study was taken from the muscles of the thigh and the keel area. At the same time organoleptic, biochemical and microscopic indicators of meat were determined.

\section{RESULTS AND DISCUSSION}

The use of the drug had a positive effect on the dynamics of the live weight of laying hens (Table 1). It was established that the live weight at the end of the experiment in the experimental group was significantly higher than in the control one by $16 \mathrm{~g}$.

Table 1: Dynamics of Body Weight Of Laying Hens, G

\begin{tabular}{|c|c|c|}
\hline \multirow{2}{*}{ Age, Days } & \multicolumn{2}{|c|}{ Groups } \\
\cline { 2 - 3 } & Experimental & Control \\
\hline 180 & $1910 \pm 3.0$ & $1907 \pm 4.0$ \\
\hline 200 & $1922 \pm 2.8$ & $1912 \pm 2.6$ \\
\hline 220 & $1931 \pm 3.2$ & $1918+4.3$ \\
\hline 240 & $1938 \pm 4.4$ & $1922 \pm 3.7$ \\
\hline
\end{tabular}

Analysis of egg production in laying hens also showed the stimulating effect of the drug on production, which was expressed in an increase in egg-laying intensity in an experimental bird by $4.7 \%$ compared with the control (Table 2 ). 
Table 2: Egg Production

\begin{tabular}{|l|c|c|}
\hline \multirow{2}{*}{\multicolumn{1}{|c|}{ Indicator }} & \multicolumn{2}{c|}{ Groups } \\
\cline { 2 - 3 } & Experimental & Control \\
\hline Total Output, PC & 1097 & 1041 \\
\hline Average Egg Weight, G & $58.6 \pm 1.2$ & $54.3 \underline{ \pm} 2.0$ \\
\hline Egg Production Per Hen, PC & 54.9 & 52.1 \\
\hline Egg Laying Intensity, \% & 91.5 & 86.8 \\
\hline
\end{tabular}

Egg mass is the most important physical indicator of food and commodity value, determining the productivity of poultry. During the study period, the average egg weight increased by $3.5 \mathrm{~g}$ in the experimental group and was higher by the end of the experiment than in the control by $4.3 \mathrm{~g}$ (by $7.3 \%$ ).

The veterinary-sanitary assessment showed that during the external examination of eggs the shells are clean, solid and strong. During the egg candling, the air chamber was seen fixed, its height along the major axis was $1.5 \mathrm{~mm}$; the yolk occupied a fixed central position, the contours were not visible; the protein was dense, translucent, evenly filling the entire periphery of the egg. On the basis of the obtained data, it was found that the egg from laying hens, receiving the test agent in addition to the diet, complies with the "Standards of Hygienic Requirements for the Quality and Safety of Production Raw Materials and Food Products". According to the principle of sorting, quality and weight of eggs, eggs of the experimental group corresponds to the first category, eggs of the control group to the second one.

5 birds from each group were slaughtered at the end of the experiment. Visible pathological changes have not been established by ante mortem examination and postmortem veterinary and sanitary examination of the carcasses and internal organs of birds of the control and experimental groups. The degree of bleeding was good. A day later after slaughter, there was a crust of drying up on the surface of the carcasses. The muscle tissue was dense; the hole from pressure by a finger was quickly straightened out. On the surface and at the depth of the cut, the smell of meat was specific, common to fresh meat of birds. The muscles in the cut are slightly wet, of pale pink color, not leaving wet spots on the filter paper. Subcutaneous and internal fatty tissue is pale yellow without foreign smell. When conducting the cooking test, the broth was clear and fragrant with a pleasant smell. Fat was collected in the form of large drops on the surface of the broth.

When conducting physical and chemical studies, it was found that the processes of maturation of meat in both groups proceeded in the same way, as indicated by the $\mathrm{pH}$ value, which did not have a significant difference between the groups and amounted to $6.1 \pm 0.12$ and $6.2 \pm 0.04$ in the white muscles, and in the red muscles it was 5.9 $\pm 0.08-6.0 \pm 0.04$. The reaction of water extracts from white and red meat to ammonia and ammonium salts with Nessler's reagent was negative in both groups. Muscle tissue enzyme peroxidase was highly active in the red muscles and inactive in the white muscles.

Microscopy of smears-prints from poultry meat of both groups did not show significant differences. In the field of view of drugs, there were 3-5 microbes in one field of view, represented by the banal microflora, which corresponds to the current standards for the good quality of poultry meat.

\section{CONCLUSIONS}

The results of the studies indicate the stimulating effect of the studied drug on the productivity of laying hens. At the same time, a veterinary-sanitary examination of poultry meat showed the absence of its negative impact on the product quality. 


\section{REFERENCES}

Olga I. Shorkina, Ilsur G. Galimzyanov, Nikita V. Nikolaev, Evgeny O. Krupin

1. Smolentsev, S.Yu., Poltaev, E.N., Matrosova, L.E., Matveeva, E.L., Ivanova, A.E., Tremasova, A.M. and Erochondina, M.A., 2018. Stimulation of rumen microflora in cattle by using probiotic concentrate, Research Journal of Pharmaceutical, Biological and Chemical Sciences, 9(2): 948-950.

2. Khristoforovich, P.K., Ravilevich, K.I., Rasimovich, S.V., Yakovlevich, T.M., Mikhailovna, T.A., Akhmadullovich, S.F. and Yurievich, S.S., 2016. Cytomorphological changes hepatorenal system combined with fever poisoning xenobiotics, Research Journal of Pharmaceutical, Biological and Chemical Sciences, 7(4): 2214-2221.

3. Anatolievna, S.E., Yurievch, P.O., Vasilevna, T.E., Viktorovna, K.T., Gennadievna, S.E., Yurievich, S.S., 2016. Development of technology lamb boiled in the skin with the use of milk-protein complex, Research Journal of Pharmaceutical, Biological and Chemical Sciences, 7(3): 839-846.

4. Semenov, E.I., Mishina, N.N., Tanaseva, S.A., Kadikov, I.R., Tremasova, A.M., Papunidi, K.K. and Smolentsev, S.Y., 2018. Systemic anaphylaxis due to combined mycotoxicosis in wister rats, Indian Veterinary Journal, 95(6): 16-19.

5. Samsonov, A.I., Semenov, E.I., Plotnikova, E.M., Smolentsev, S.Y., Nikitin, A.I., Papunidi, K.K. and Tremasov, M.Y., 2018. Mink farming and mycotoxicosis, Indian Veterinary Journal, 95(5): 52-55.

6. Ilyasovich, S.E., Mikhailovna, T.A., Rasimovich, S.V., Yurievich, S.S., Akhmadullovich, S.F., Khristoforovich, P.K. and Yakovlevich, T.M., 2016. Efficiency of application of a polysaccharide enterosorbent of "Fitosorb" for prevention of the combined mycotoxicoses, Research Journal of Pharmaceutical, Biological and Chemical Sciences, 7(4): 2229-2237.

7. Egorov, V.I., Valiullin, L.R., Biryulya, V.V., Nabatov, A.A., Smolentsev, S.Y., Papunidi, K.Kh. and Nikitin, A.I. 2018. Toxicity indices of uracil derivatives on lung epithelial cells, Indian Veterinary Journal, 95(6): 33-36.

8. Matveeva, E.L., Korosteleva, V.P., Papynidi, E.K., Yusupova, G.R. and Smolentsev, S.Y., 2015. Electron microscopic evaluation of the impact on microorganisms of quaternary ammonium compounds, Research Journal of Pharmaceutical, Biological and Chemical Sciences, 6(4): 207-209.

9. Dmitriyevich, C.E., Vladimirovich, O.A., Leonidovich, R.A., Valeryevna, H.L., Sergeevna, N.C. Vladimirovich, M.E. and Yurievich, S.S., 2016. The russian heavy draft milk type mares characteristics. Research Journal of Pharmaceutical, Biological and Chemical Sciences, 7(2): 1930-1933.

10. Popov, S.V., Kalyuzhnyi, I.I., Smolentsev, S.Yu., Gataullin, D.H., Stepanov, V.I., Nikitin, A.I. and Zakirova, G.Sh., 2018. Acidbase homeostasis indices upon electric neurostimulation therapy of calves with acute pulmonary pathologies, Research Journal of Pharmaceutical, Biological and Chemical Sciences, 9(3): 553-556.

11. Valiullin, L.R., Idiyatov, I.I., Egorov, V.I., Saitov, V.R., Papunidi, K.K., Raginov, I.S. and Smolentsev, S.Yu., 2017. A study into the safety of novel bioresorbable matrices for repairing bone tissue defects, Bali Medical Journal, 6(2): 88-91.

12. Babu, Rajesh, et al. "Effect of feeding solvent extracted and detoxified karanj (Pongamia glabra Vent) cake on egg quality parameters in commercial layer chicken." International Journal of Agricultural Science and Research (IJASR) 5.6 (2015): 289-292.

13. Al-Daraji, Hazim Jabbar. "Effect of supplementing the diet of Japanese quail (Coturnix coturnix japonica) with sesame (Sesamum indicum) oil and seeds on egg quality characteristics." International Journal of Agricultural Science and Research (IJASR), 3.2 (2013): 245-256. 